\title{
CrimRxiv
}

\section{Countering distrust in illicit online networks: the dispute resolution strategies ofcybercriminals}

Benoit Dupont, Jonathan Lusthaus

Published on: Mar 03, 2022

DOI: 10.21428/cb6ab371.1b800d7a

License: Creative Commons Attribution 4.0 International License (CC-BY 4.0). 
